\title{
The Use of Problem based Learning to Improve Elementary School Students' Critical Thinking Skills
}

\author{
${ }^{1}$ Mar'attus Solihah, ${ }^{2}$ Anggraeni Mashinta Sulistyani \\ ${ }^{1}$ maratussolihah96@gmail.com, ${ }^{2}$ amashintas@gmail.com \\ ${ }^{1,2}$ PGSD STKIP Majenang
}

\begin{abstract}
This study aims to determine the effect of the use of Problem Based Learning towards elementary schools students' critical thinking skills. The study was conducted at two elementary schools in Cilacap Regency, where two classes were treated as experimental classes while the two classes functioned as control classes. Critical thinking skill is measured using tests developed by researchers in accordance with sub-themes of learning (digestive system and human nutritional needs). The validity and reliability of the instrument was evaluated using expert judgment which was then tested on the sixth grade students of Elementary School Kalierang 05. In order to find out the improvement of critical thinking skills pre-test and post-test were carried out both in the experimental classes and control classes. The next stage is analyzing the data quantitatively by using the t-test. The results of data analysis showed that there was an increase in critical thinking skills that were higher in the classroom using problem based learning models. But the increase of students' critical thinking skills is still relatively low.
\end{abstract}

Keywords: Critical Thinking Skil; Problem Based Learning.

\section{Introduction}

Globalization forces people to change the way they fulfill their daily lives. The work competency, economic development, the speed of innovation, the extent of communication networks, the opening of access to information, and the discovery of effective and efficient technology in all fields has changed the face of the world to become more dynamic and uncertain. Facing all these changes, humans cannot continuously respond in the same way. All areas of life are dragged along by the swift flow of change and leave no other choice but to adapt to the same speed. Likewise the world of education which is the center of learning for millennium human being, must be able to prepare students to respond and adapt to the current needs. The ability needed by students as a provision to face an increasingly dynamic world is no longer the same as a few decades ago. Preparing students to face the world of work and survive in the 21 st century is something that is not easy; it requires planning, continuous processes, and consistency.

Wagner and Change Leadership Group from Harvard University conducted research by interviewing thousands of business people, educators, volunteers and company leaders to find out the future skills to survive. Based on the research it was concluded that critical thinking skill is one of the seven skills that must be possessed by students to prepare themselves in the world of the 21st century[1]. Similar conclusions were also generated from the Assessment and Teaching Consortium of 21st Century Skill (AT21CS) which divided 21st century skills into four groups namely ways of thinking, ways of working, tools for working, and living in the world. Ways of working consists of creativity, innovation, critical thinking, and problem solving skills [2]. 
Thinking skills need to be taught as early as possible to students so that later constructivist thinking habits have been embedded and have an established foundation since children are still in childhood phase. The good effort has been seen from the government in developing the latest curriculum, 2013 curriculum which emphasizes the scientific approach in the learning process. But in reality, the learning process in schools has not completely shifted from the old paradigm that is teacher-centered to be student-centered. Learning in schools has not placed students as active learners who independently construct their understanding.

Based on data from the OECD[3] the current learning pattern is still dominated by learning that is transmission, teachers convey what is in the book or learning resources to students. The evaluation system used is mostly in the form of recalling what was said by the teacher. Learning patterns like this are still widely used because they are easier to apply and do not require complicated pedagogical abilities. Teachers only need to convey what they know, follow established standards, and pursue minimum graduation rates targeted by the school. However, learning patterns like this only make students full of information but poor in application when finding new contexts, making students unable to communicate knowledge in a more complex form, and making students unable to do contextual problem solving or develop creativity.

Critical thinking skills need to get attention in learning. The ability to think critically can be grown if there is habituation done. Learning that aims to foster critical thinking skills must be student-centered learning. One learning model that can encourage students to be actively involved in the learning process is Problem Based Learning (PBL). In PBL students will learn the importance of working in groups and collaborating to develop cognitive abilities, understand problems, collect important data, analyze data, and elaborate data to find solutions. Dialogue is very important in PBL so students are not trapped in personal assumption. All series of processes are ways that can lead students to develop critical thinking skills through problem solving [4].

Growing critical thinking skills should begin at an early age. Heyman and Legare found that children aged 7-10 years have an awareness of the possibility of distorting the truth[5]. According to Arends [6] PBL presents a variety of authentic and meaningful problematic situations for students, which can serve as a springboard for investigation.

\section{Related Works/Literature Review Elementary Science Learning}

Basically science is the lesson that studies all natural phenomena that occur around humans then tries to explain those phenomena. Learning science is very closely related to scientific methods. The scientific method is a series of activities to find the truth of science which refers to the principle of logico-hypothetico-verification [7].

Primary school students are children who are in the age range 7-13 years. According to the cognitive development that Piaget proposed, children aged 7-11 years were in the phase of concrete operational development and the age of 11 years and above had entered the formal operational stage. Referring to the developmental stages proposed by Piaget, low-grade elementary students are still at a concrete operational stage, while high-class students begin to enter formal operational stages. In the concrete operational phase students have been able to do logical thinking activities, while in the formal operational phase students are able to think complexly like adults.

Learning Science is the process of constructing knowledge (science) through children's thinking activities. Students are guided to explore problems, look for explanations 
about the phenomena that are seen, and conduct experiments to solve problems faced. According to Sulistyani [8] through the science process, children can carry out simple experiments to train children to think logically. The introduction of science in children emphasizes processes rather than products. Science allows children to explore various objects both living and non-living things, and symptoms of events in solving a problem. The scientific process is known as the scientific method which generally covers observation, finding problems, conducting experiments, analyzing data, and drawing conclusions. Seeing the cognitive development characteristics of elementary school students, they will be better able to understand learning when the object of study presented is accompanied by real examples that are close to everyday life. This means that teachers must be able to present real, close science learning, while at the same time attracting students' curiosity.

\section{Problem based Learning}

The Problem Based Learning (PBL) model or problem based learning is a learning model for students who are designed to solve the problems presented. According to Trianto[9], the PBL model is a learning model that is based on the many problems that require authentic inquiry, namely investigations that require real resolution of real problems. Problem-based learning is a learning model that encourages students to think critically, improve problemsolving skills, and apply science to everyday problems. Student-centered learning and the teacher's role in directing students is more limited. Learning is active, integrated, cumulative, and connected. In PBL, students will at least conduct discussion, reflection, research; create projects, and present results [10].

The process in PBL contains several essential steps as follows: 1) determine the problem; 2) analyze problems and produce problems in learning; 3) find and report; 4) propose solutions and reflections; 5) overview, integration, and evaluation that prioritizes independent learning to bridge one stage to the next [11]. The following is the PBL process and the process of obtaining knowledge in Figure 1.

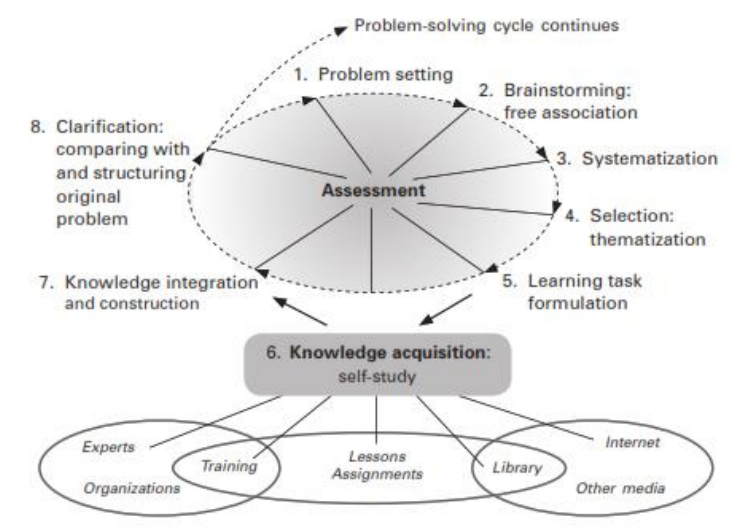

Figure 1. Problem based Learning Process and the process of obtaining knowledge Source: Poikela \& Poikela (2006)[12]

\section{Critical Thinking Skill}

Since Bloom's discovery in 1948 concerning the purpose of the learning process which consists of knowledge, understanding, application, analysis, synthesis, and evaluation, critical thinking skills are a subject that is widely discussed in the world of education. Critical 
thinking ability has experienced the development of definitions since it was first debated until nowadays, but one thing that never changes that critical thinking is the need to produce effective solutions to a complex problem. Students will feel that their learning is meaningful when they have a clear final goal [13].

Weissinger[14] states that critical thinking must contain four things: foundation skills, knowledge base, willingness to question, and self-reflection. If a person has basic skills and basic knowledge but does not have the desire to ask or control his own learning process, then the person is not called to have the ability to think critically. In other words, a critical thinker must not only have basic skills in critical thinking, but also must have the will to use it in contexts understood by him and then be able to use it as a basis for evaluation. Here is the Venn diagram of Weissinger's definition of critical thinking.

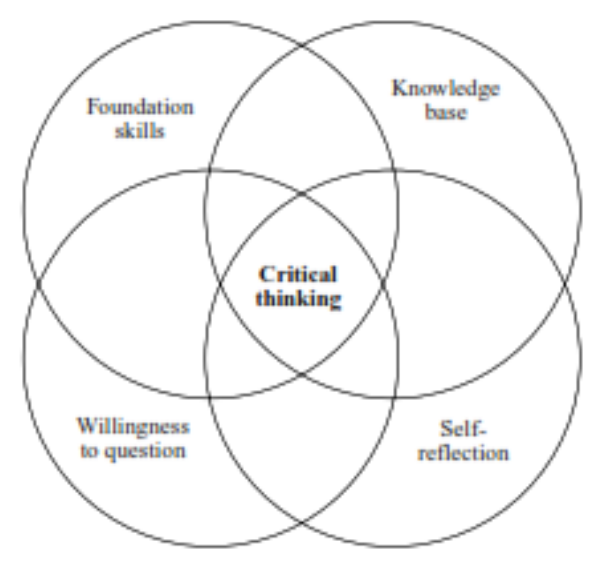

Figure 2. Four Basics and Relationships between Components in the Definition of Critical Thinking

Source : Weissinger (2004)

Richard Paul \& Linda Elder [15] stated that critical thinking can be explained in various definitions, depending on the goals of each individual. However, they provide the most appropriate definition of critical thinking to be measured as follows.

Critical thinking is the process of analyzing and assessing thinking with a view to improving it. Critical thinking presupposes knowledge of the most basic structures in thinking (the element of thought) and the most basic intellectual standards for thinking (universal intellectual standards). The key to the creative side of critical thinking (the actual improvement of thought) is in restructuring thinking as the result of analyzing and effectively assessing it.

There are nine standards of intellectual thinking that can be used as indicators of critical thinking, namely: 1. clarity, 2. accuracy, 3. precision, 4. relevance, 5. depth, 6. breadth, 7. logic, 8. significance, 9. fairness [16]. In connection with the Mapela \& Siew science field [17] recommends the ability to think critically for 11-year-olds to focus on comparing and contrasting skills, sequencing skills, and the ability to identify cause and effect. Based on the literature review above critical thinking skill in this study is defined as the need to find effective solutions to problems in the realm of science that involves comparing skills, sorting in order, and identifying cause and effect. 


\section{Material \& Methodology}

This research has been carried out in SD Negeri Gunungreja 02 and MI Mafatihul Huda Cipari. The study was conducted on students in grades 5A and 5B in the two schools. This research is a quasiexperimental study with a non-randomized control group pretest-posttest design. The research instruments used were critical thinking ability tests and observation sheets. Critical thinking skills tests are used to measure students' critical thinking skills in the form of multiple choice tests totaling 20 items. Observation sheets are used to determine student activity during the learning process using PBL learning models. The improvement of students' critical thinking skills was analyzed based on the mean normalized gain values as follows.

$$
g=\frac{S_{f}-S_{i}}{100-S_{i}}
$$

Information:

$\mathrm{Sf}=$ final test $($ posttest score)

$\mathrm{Si}=$ initial test (pretest score)

$\mathrm{g}=$ gain (increase)

Interpretation of criteria for enhancing students' critical thinking skills refers to Hake's[18] gain value criteria. Data analysis technique used to determine the effect of PBL on students' critical thinking skill was t-test. As before the analysis of the research data, the analysis prerequisite test in the form of normality test and homogeneity test was done. Before carrying out the research, the instrument that would be used was tested first its validity and reliability. The instrument tested was a critical thinking skills test consisting of 25 multiple choice items to measure elementary school students' critical thinking skills in the human food digestive system material. The question was then tested on students SD Negeri Kalierang 05 Class 6 with a total of 23 students. The results of the instrument trial were then processed using the QUEST program to see its validity and reliability.

\section{Results and Discussion}

\section{Students Critical Thinking Skill Data}

The following is the experimental test data for critical thinking ability tests, namely the students' pre-test and post-test scores.

Tabel 1. Student Critical Thinking Skill Data

\begin{tabular}{ccccc}
\hline \multirow{2}{*}{ Description } & \multicolumn{2}{c}{ Control Class } & \multicolumn{2}{c}{ Experimental Class } \\
\cline { 2 - 5 } & \multicolumn{2}{c}{$\mathrm{n}=42$} & \multicolumn{2}{c}{$\mathrm{n}=41$} \\
\cline { 2 - 5 } Rata-rata & Pretest & postest & Pretest & Postest \\
\cline { 2 - 5 } & 29,64 & 40,72 & 27,07 & 44,27 \\
\hline Standar Deviation & 10,67 & 13,63 & 7,33 & 12,02 \\
\hline Varians & 113,89 & 186,06 & 53,72 & 144,45 \\
\hline Maximum score & 55 & 65 & 40 & 70 \\
\hline Minimum score & 15 & 20 & 15 & 20 \\
\hline
\end{tabular}

Based on the table, it can be seen that the average value of the control class pretest and experimental class is not too far in the amount of 29.64 for the control class and 27.07 for the experimental class. After the average posttest was carried out the value for the higher experimental class was 44.27 compared to the control class which averaged 40.72 . The maximum score for the control class rose from 55 in the pretest to 65 in the posttest. Whereas for the experimental class the highest pretest value was only 40 and rose to 70 after being 
treated. Both classes have the same minimum score for pretest and posttest, namely 15 and 20 . To see the change in the value of critical thinking skills from pre-test and post-test can be seen in the diagram in Figure 3.

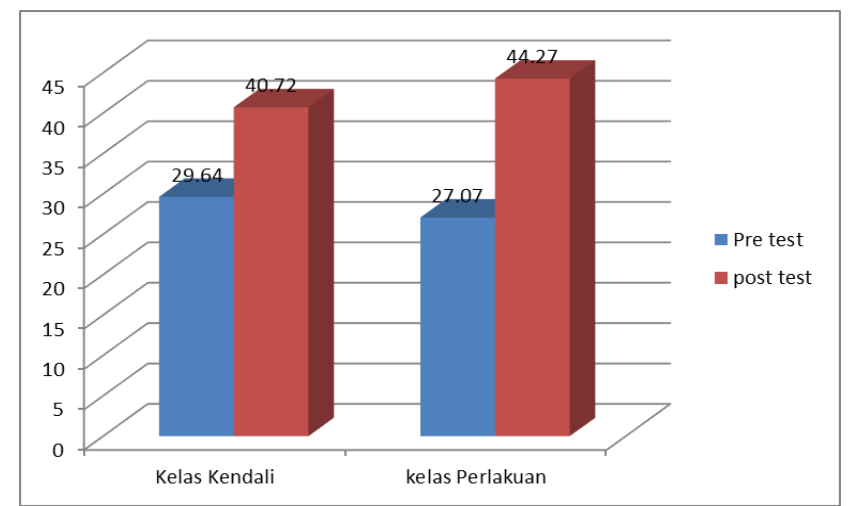

Figure 3. The chart changes the value of students' critical thinking abilities

Based on the pretest and posttest values that have been described previously, it can be calculated the magnitude of the increase in value for students' critical thinking skills using the normalized gain formula. The magnitude of the increase in both variables can be seen in Table 2.

Tabel 2. Gain Score Students' Critical Thinking Skill

\begin{tabular}{lc}
\multicolumn{1}{c}{ Class } & $\begin{array}{c}\text { Critical thinking skills } \\
\text { Gain }\end{array}$ \\
\hline Control & 0,159 \\
\hline Experimental & 0,237 \\
\hline
\end{tabular}

To see the visual comparison of differences in the improvement of critical thinking skills from the control class and experimental class can be seen from the diagram in Figure 4.

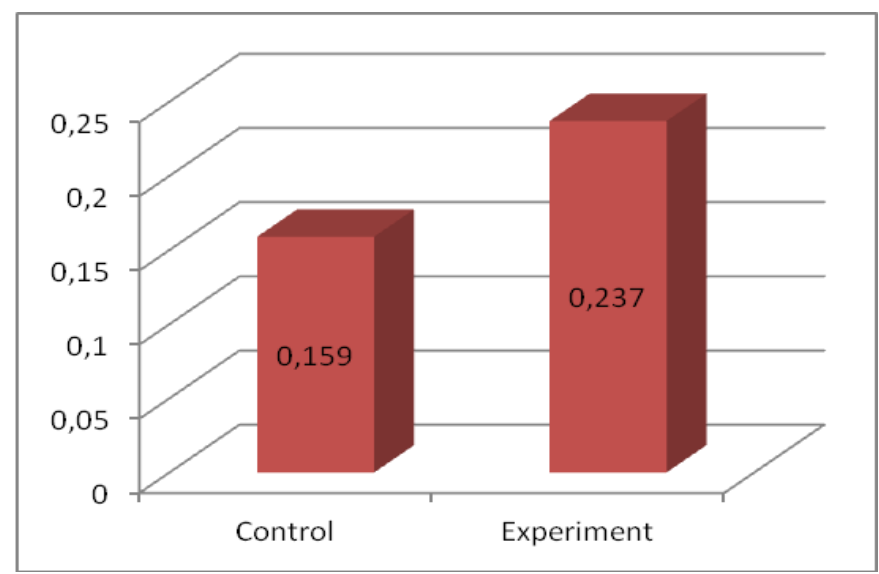

Figure 4. Students' critical thinking skill gain score diagram 
From the diagram above, it is clear that the improvement of students' critical thinking skills in both classes is low, but it can be seen that critical thinking skills in the treatment class are higher than the control class.

\section{Hypothesis Testing}

Before testing the research hypothesis, an analytical prerequisite test was taken in the form of normality test and homogeneity test. Data was stated to be normally distributed if the significance value was greater than $\alpha(0.05)$. The following table is normality test by using SPSS 20.

Table 3. Normality Test

\begin{tabular}{cccc}
\hline Group & Sig & $\alpha$ & Conclusion \\
\hline Control Class & 0,200 & 0,05 & Normal \\
\hline Experimental Class & 0,200 & 0,05 & Normal \\
\hline
\end{tabular}

Based on the significance value obtained is equal to 0.200 with a value greater than alpha (0.05), it can be concluded that the two classes come from groups that are normally distributed. Then to determine the homogeneity of the two groups tested using Lavene statistics with the following results.

Table 4. Homogeinity Test

\begin{tabular}{llll}
\hline Lavene statistics & Sig & A & Conclusion \\
\hline 0,000 & 0,987 & 0,05 & Homogeny \\
\hline
\end{tabular}

The hypothesis for this study is: $\mathrm{H}_{0}=$ there is no difference in the improvement of critical thinking skills between classes that use problem based learning with classes that use conventional methods; $\mathrm{H}_{1}=$ there are differences in the improvement of critical thinking ability between classes that use problem based learning with classes that use conventional methods. To test this, t-test is used by using SPSS 20. The research hypothesis (H1) is accepted if the significance value is greater than alpha. The results of the t test can be seen in the following table.

Table 5. Hypotesis Test

\begin{tabular}{ccc}
\hline T value & Sig & A \\
\hline$-2,061$ & 0,011 & 0,05 \\
\hline
\end{tabular}

In the table generated a significance value of 0.011 which is smaller than alpha (0.05) which means the research hypothesis is accepted. It means that classes that use problem based learning models have a better average improvement than conventional classes.

\section{Discussion}

The purpose of this study is to find out the effect of using problem-based learning models on students' critical thinking skills. To achieve this goal hypothesis testing has been carried out with the results of classes that apply problem based learning to have critical thinking skills that are better than classes that use conventional learning. The statement "better" is based on the average value of critical thinking skills from both classes. The experimental class has a higher critical thinking average gain of 0.237 compared to the control 
class which only increases by 0.159 . The difference in the increase in the two classes is statistically significant.

The results of this study are in line with several previous findings which state that PBL enhances students' critical thinking skills. As happened in learning, students become more active in asking questions because the theme of learning raises the problems experienced in the daily life. In this study students discuss problems in the digestive system and malnutrition problems.

Although stated statistically significant but deserves attention for researchers because the average posttest scores in both groups are still low, which is under 50 of the total score of 100. The application of problem based learning to students is one of the efforts that can be done to improve critical thinking skills. The low value generated reflects the conditions in both schools that do not familiarize students to develop higher-order thinking skills. This is in accordance with the initial observations conducted by researchers that science learning is still carried out conventionally and is memorized. Students only refer to one textbook that is only shared when learning begins and is withdrawn by the school when the lesson is over. Primary schools chosen by researchers are schools in rural areas with minimal facilities and very conventional learning patterns.

Critical thinking is the ability that students can sharpen and develop through a series of exercises and habituation on an ongoing and consistent basis. Synder [19] stated that critical thinking requires an active learning situation and deep student involvement. In addition students need to have a role model of the teacher about how to think critically because not all students are born with high critical thinking skills and not all conditions where students live requires them to think critically. In line with Synder, Florea \& Hurjui [20] stated that critical thinking depends on two factors: the learning situation experienced by students (static context) and the stage of development of students' critical thinking (dynamic context). This means that if students are not used to being taught to develop their thinking skills, students must start from the lowest stages of critical thinking. Along with habituation and conditioning of learning situations that lead students to critical reasoning, students will become more accustomed and have high achievement in critical thinking skills.

\section{Conslusion}

Based on the data that has been processed, it can be concluded that problem based learning can improve the critical thinking skills of elementary school students. In this study the improvement of critical thinking skills achieved by students is relatively low. It needs to be mapped further about the level of students' critical thinking skills in elementary schools in Cilacap between urban and rural areas that are still relatively remote so we have a complete picture of students' thinking level today.

\section{Acknowledgement}

Researchers would like to express their deepest gratitude to the Ministry of Research, Technology, and Higher Education of the Republic of Indonesia for supporting all funds in this study. 


\section{References}

[1] C. L. Scott, "The Futures of learning 2: what kind of learning for the 21st century?; Education, research and foresight: working papers; Vol.:14; 2015," 2015.

[2] R. Corporation, Teaching and Learning 21 st Century Skills: Lesson from the Learning Science. RAND Corporation, 2012.

[3] OECD, Education at a Glance 2014: OECD Indicators. OECD Publishing, 2014.

[4] O.-S. Tan, Problem Based Learning Innovation: Using Problem Based Learning in the 21st Century. Shenton Way: Cengage Learning Asia, 2003.

[5] E. . Lai, Critical Thinking: A literature Review. Pearson. .

[6] R. Arends, Learning to Teach (Helly, Prajitno \& Sri, Mulyani .Terjemahan). New York: McGraw Hill Company, 2008.

[7] J. . Suriasumantri, Filsafat Ilmu. Jakarta: Pustaka Sinar Harapan, 2015.

[8] A. M. Sulistyani, "Pengenalan Sains bagi Anak Oleh Orang Tua di Lingkungan Keluarga," Insania, vol. 21, no. 1, pp. 102-115, 2017.

[9] Trianto, Model Pembelajaran Terpadu. Jakarta: Bumi Aksara, 2010.

[10] B. B. Levine, Energizing Teacher Education and Professional Development with Problem Based Learning. United States: Association for Supervision and Curriculum Development, 2001.

[11] C. . T. \& S. C. O. S Tan, Problems And Creativity. Dalam O. S. Tan, Problem Based Learning and Creativity. Singapore: Cengage Learning Asia, 2009.

[12] E. P. \& P. S, Problem Based Curicula- Theory, Development and Design. In Understanding Problem Based Learning. Findland: Tampere University Press, 2006.

[13] S. V, Critical Thinking in the Elementary Classroom: Problems and Solution. EPS Update, 2002.

[14] W. P. A, Critical Thinking, Metacognition, and Problem Based Learning. Dalam T. O. Seng, Enhancing Thingking Through Problem Based Learning Approaches. Singapore: Cengage Learning, 2004.

[15] P. \& L. E. D. R, "The Foundation for Critical Thinking," The Foundation for Critical Thinking, 2007. [Online]. Available: www.critical thinking.org.

[16] R. P. \& L. Elder, "Critical Thinking: Intellectual Standars Essential to Reasoning Well Within Every Domain of Human Tgought," J. Dev. Educ., pp. 32-36, 2013.

[17] R. M. \& N. M. Siew, "The Development and Validation of a Test of Science Critical Thinking for Fifth Grades," Springerplus, vol. 4, no. 741, 2015.

[18] G. S. R. Analyzed Change, Hake, "American Educational Research Assosiation's Division D. Management and Research Methodology." [Online]. Available: http//www.physics indiana edu/-sdi/AnalyzingChange-Gain.

[19] S. L. G, Snyder \& M.J, "Teaching Critical Thinking and Problem Solving Skills," Delta Pi Epsil. J., vol. 1, no. 2, pp. 90-99, 2008.

[20] E. Nadia Mirela, Florea \& Hurjui, "Critical Thinking in Elementary School Children," in Procedia - Social and Behavioral Sciences, 2015, pp. 565-572. 